\title{
Lumen
}

Selected Proceedings from the Canadian Society for Eighteenth-Century Studies

\section{The Varronian, the Various, and the Political: $A$ Tale of $a$ Tub, The New Atalantis and Early Eighteenth-Century Fiction}

\section{David Oakleaf}

Volume 34, 2015

URI : https://id.erudit.org/iderudit/1028513ar

DOI : https://doi.org/10.7202/1028513ar

Aller au sommaire du numéro

Éditeur(s)

Canadian Society for Eighteenth-Century Studies / Société canadienne d'étude du dix-huitième siècle

ISSN

1209-3696 (imprimé)

1927-8284 (numérique)

Découvrir la revue

Citer cet article

Oakleaf, D. (2015). The Varronian, the Various, and the Political: A Tale of a Tub, The New Atalantis and Early Eighteenth-Century Fiction. Lumen, 34, 93-108. https://doi.org/10.7202/1028513ar 


\title{
The Varronian, the Various, and the Political: A Tale of a Tub, The New Atalantis and Early Eighteenth-Century Fiction
}

\author{
DAVID OAKLEAF \\ University of Calgary
}

Although Jonathan Swift and Delariver Manley would find themselves in bed together politically as propagandists for the Tory administration headed by Robert Harley, they form an odd couple. A Tale of a Tub (1704) and Secret Memoirs and Manners of Several Persons of Quality, of Both Sexes, from the New Atalantis, An Island in the Mediterranean (1709) in particular seem so ill assorted that even critics of satire seldom consider them together. ${ }^{1}$ Without minimizing the oddity of the project, I will suggest the value of considering these texts together formally, politically, and commercially. A Tale and New Atalantis are both Varronian (alternatively, Menippean) satires pressed into the service of partisan politics. Politically, their authors learned, both were dangerously intemperate. For his contribution to the sectarian politics that was inseparable from the politics of state, the clergyman Swift marred his chances for preferment within the Church of England-the Church by law established that he was, he thought, defending from its

1. Both rigorous and imaginative about his chosen form, Howard D. Weinbrot mentions Manley only twice in Menippean Satire Reconsidered: From Antiquity to the Eighteenth Century (Baltimore, MD: Johns Hopkins University Press, 2005); programmatically inclusive and skeptical about generic labels, Ashley Marshall also devotes scant attention to Manley while establishing Swift's context in The Practice of Satire in England, 1658-1770 (Baltimore: Johns Hopkins University Press, 2013). An honourable exception is Carole Fabricant, "The Shared Worlds of Manley and Swift," in Pope, Swift, and Women Writers, ed. Donald C. Mell (Newark; London: University of Delaware Press; Associated University Presses, 1996), 154-78. 
foes. Its members, he later grumbled, "are not always very nice in distinguishing between their Enemies and their Friends." For her partisan satire of powerful members of the Whig ministry, the Tory Manley faced consequences even more serious. After the publication of the second volume of the New Atalantis, she was arrested on charges of seditious libel. ${ }^{3}$ The boundary between politics and fiction was porous: Swift and Manley, like their contemporary Daniel Defoe, faced harsh real-world reprisals for what they wrote. Finally, partly on the strength of such vigorous reader responses, I would like to associate A Tale and New Atalantis as commercial successes that (along with some contemporary satire) merit consideration with the early novel. For A Tale and New Atalantis are both fictions that sold remarkably well in the turbulent marketplace that was spawning the miscellaneous form (or cluster of forms) that we dignify as the novel. This market was highly politicized. The ${ }_{1694}$ Triennial Act required elections to Parliament at least every three years, and sharp partisan differences meant that they were fiercely contested. The (related) lapse of the Licensing Act in 1695 eliminated prepublication censorship of printed works, including the partisan propaganda needed to sway public opinion. Ambitious writers who could catch the taste of the town-that is, write for sale what readers wanted to buy-possessed a skill that the powerful were willing to reward with preferment or, lower down the social scale, cash. Even writers who were taking advantage of this situation, as Swift was trying to do in A Tale, disparaged their rivals' self-serving and subliterary venality: "Fourscore and eleven Pamphlets have I writ under three Reigns," brags the Grub-Street Teller of Swift's Tale, "and for the Service of six and thirty Factions" (A Tale, 44). Writers like Swift prospered better than smaller fry in the predatory world of commercial publication, but they swam in the same pool. ${ }^{4}$

2. Jonathan Swift, A Tale of a Tub and Other Works, ed. Marcus Walsh (Cambridge: Cambridge University Press, 2010), 6 (roman substituted for italics); this edition hereafter cited parenthetically by page number as A Tale).

3. Ruth Herman, The Business of a Woman: The Political Writings of Delarivier Manley (Newark: University of Delaware Press; London: Associated University Presses, 2003), 72-73.

4. For the claim that Defoe and Pope simply covered their tracks better than Swift, see Michael Treadwell, "Swift's Relations with the London Book Trade to 1714," in Author/Publisher Relations During the Eighteenth and Nineteenth Centuries, ed. Robin Myers and Michael Harris (Oxford: Oxford Polytechnic Press, 1983), 2; see 
"In the largest terms," Marcus Walsh observes, "the Tale itself belongs to the genre or anti-genre we have learnt to call Menippean satire" (A Tale lv), the literary kind central to formalist readings of A Tale. Such an identification leaves open more questions than it settles, however, as Walsh's cautious phrasing suggests. Even less enamored of generic labels, Ashley Marshall argues that we should read a full range of contemporary satire, not just a few agreed classics, registering satire's daunting heterogeneity. "Swift as early eighteenth-century satirist," she concludes, "belongs not to the world of the Scriblerians but to that of Defoe, Tutchin, Maynwaring, and the other religiopolitical satirists" a group with which I will shortly associate Manley. ${ }^{6}$ Yet it is a matter of fact that when Manley dedicated the second volume of the Atalantis to the Duke of Beaufort, she publicly claimed Swift's form, then usually called Varronian satire:

The New Atalantis seems, My Lord, to be written like Varronian Satyrs, on different Subjects, Tales, Stories and Characters of Invention, after the Manner of Lucian, who copy'd from Varro.?

Manley, it is true, acquired her tradition outside the kind of classical schooling that shaped Swift but from which most women were excluded. For the pre-eminent scholar of Menippean (or Varronian) satire's transmission to and transformations within the eighteenth century, Manley's claim demonstrates her familiarity with Dryden's essay on satire, which synthesized the scholarship of André Dacier and Isaac Casaubon: "Thanks to Dryden, Varro and exhortation to virtue," Howard D. Weinbrot reckons, "Varro and the Roman formal verse

also J. A. Downie's ground breaking Robert Harley and the Press: Propaganda and Public Opinion in the Age of Swift and Defoe (Cambridge: Cambridge University Press, 1979).

5. A recent example is Weinbrot, Menippean Satire, 115-61; Weinbrot's preceding survey of the form in the eighteenth century is invaluable.

6. Marshall, Practice of Satire, 180-81.

7. Delarivier Manley, Selected Works of Delarivier Manley, 5 vols., ed. Rachel Carnell and Ruth Herman (London: Pickering and Chatto, 2005), 2: 152; this edition hereafter cited by volume and page as Manley. This edition frames Manley's work splendidly; regrettably, close work with the text of the Atalantis reveals textual errors, often the kind typical of optical character recognition (OCR): "is [for "if"] the Performance be not" (2: 7), "inessable [for "ineffable'] Charms" (2: 14), "receive 'em I yet Custom" [for "receive 'em! yet Custom"] and "preominence" [for "preeminence"] (2: 17), "tis asfirm'd" [for "'tis affirm'd"] (2: 24), "piece of her. Ear" [for "piece of her Ear"] (2: 99), and so on. 
satirists, seem to be part of Manley's satiric patrimony." Varronian satire was a form available to contemporary satirists, and Manley uses it knowingly.

Since Manley (b. between 1667 and 1671) belongs to the same generation as Defoe (b. 1660) and Swift (b. 1667), and since she too is a successful satirist and propagandist of note, it is disappointing that Marshall does not give her more space among her contemporaries. The Atalantis is very different from A Tale, but a form like Menippean satire is a playing field, not a template. The domestic quarrel in which a thinly disguised Sarah Fyge Egerton throws a hot apple pie and a pound of butter in the face of her husband, the clergyman Thomas Egerton, Carole Sargent shows, is actually a bit of complexly allusive religiopolitical satire nestled within Manley's larger Tory project: it mocks a compliant High Church's passivity in the face of Whig abuse.? The Atalantis's sexualized political relationships, sometimes thought to reveal Manley's distinctive touch, pretty clearly develop a satiric strategy conspicuous in the poems on affairs of state that were a staple of post-Restoration and post-Revolution polemic, including Andrew Marvell's painter poems. ${ }^{10}$ It is also a bit of personal score-settling, of course, something Swift too enjoyed when he incorporated his critics into the notes of A Tale in the revised edition of 1710 . But both writers coordinate personal animus with the hunt for bigger game.

Varronian satire had a lot to recommend it to a writer in Swift's or Manley's position. In a splendid essay on Manley and Varronian satire, Aaron Santesso insists not only on this satiric form but also on the eighteenth-century reputation of Marcus Terentius Varro. Varro's celebrated erudition, his satire of pedantry, his repute as "a virtuous, honest citizen, and an opponent ... of abuses in religion”-this last is Santesso's phrase-all mark him as a viable model for Swift as well as Manley. In a later critique of the free thinker Anthony Collins, as Santesso observes,

8. Weinbrot, Menippean Satire, $3^{8 .}$

9. Carole Fungaroli Sargent, "How a Pie Fight Satirizes Whig-Tory Conflict in Delarivier Manley's The New Atalantis," Eighteenth-Century Studies 44, no. 4 (Summer 2011): 515-33.

10. A useful introduction to this milieu is W. A. Speck, Literature and Society in Eighteenth-Century England 1680-1820 (London and New York: Longman, 1998), $31-47$. 
Swift presents Varro as "the antitype of the Modern."1l Any principled political writer could place her- or himself under the banner of a learned writer convinced that luxury leads to corruption and decline-a standard trope of eighteenth-century opposition polemic. ${ }^{12}$ In the arena of Varronian satire, Manley can display what Sargent calls "the creative outrage animating so much of The New Atalantis"-a phrase that captures Varronian satire's appeal for Swift, too. ${ }^{13}$ Nobody can doubt the genuine indignation that Swift and Manley express from their different partisan positions. Santesso is therefore wrong when he argues that the generic is the political; that is, that Varronian satire, is inherently Tory. ${ }^{14}$ Varro embodied the incorruptible republican virtue more often associated with the figure of Cato Uticensis, who appealed to Whigs and Tories alike. Admired by Swift, Cato also inspired Addison, who helped to establish Cato's vogue when wrote the play about him that made an incorruptible republican virtue of the Whigs' banishment to the opposition benches in 1710. In Cato's Letters (1720-23), the Whigs John Trenchard and Thomas Gordon mount a trenchant assault on the corruption behind the South Sea Bubble.

Since Whigs and Tories could occupy the same high moral ground, leaving it uncertain what it means to call someone a Whig or Tory, the very heterogeneity of Varronian satire may be politically expressive. Strikingly, political parties themselves were self-divided, as were individuals within them. Even in Atalantis, Manley occasionally trains her guns on a Tory; for example, Henry St. John, later Viscount Bolingbroke, whose admiration for the pro-War Duke of Marlborough aroused Tory hostility (Manley, 2: 109-10 \& 337nn330-32). A key to a biography of the celebrated courtesan Sally Salisbury identifies the biography's Signor Gambolini as Lord Bolingbroke: St. John's notorious libertinism and "Mercurial Disposition" left him vulnerable to the kind of caricature Manley dished out to the Whigs. ${ }^{15}$ Seconding a hint by Ruth

11. Aaron Santesso, "The New Atalantis and Varronian Satire," Philological Quarterly 79, no. 2 (Spring 2000): 191-92, 196, 182-83.

12. James William Johnson, The Formation of English Neo-Classical Thought (Princeton, NJ: Princeton University Press, 1967), 48-49.

13. Sargent, "How a Pie Fight," 530.

14. Santesso, "New Atalantis," 195-99.

15. Charles Walker, Authentick Memoirs of the Life, Intrigues, and Adventures of the Celebrated Sally Salisbury. With True Characters of Her Most Considerable Gallants [1723], in Nightwalkers: Prostitute Narratives from the Eighteenth Century, ed. Laura J. Rosenthal (Peterborough, ON: Broadview, 2008), 32-35, quoting 33. 
Herman, Rachel Carnell suggests that "the miscellaneous quality of Manley's text might also be read as a way of yoking together" factions within the Tories themselves:

Manley's puzzling decision to dedicate the work to Henry Somerset, second Duke of Beaufort, a known Jacobite, when she herself apparently harboured no Jacobite sympathies, might be explained by her interest in helping to yoke "varying factions of the Tory party into allegiance with each other." (Manley, 1: 21-22) ) $^{16}$

Manley certainly deserves credit for finding a narrative form that could accommodate the jostling herd. Nevertheless, yoking these oxen to the same plough sounds more like a wish than a plan. Toni Bowers shows that Manley's dedicatee and ideal Tory, Beaufort, was a Jacobite who belonged to an illegitimate royal line that had been legitimated after the fact-as many had whiggishly hoped the Duke of Monmouth's might be. Beaufort encapsulated within himself some of the divided loyalties apparent within the larger body of Tories. ${ }^{17}$

On the terrain muddied by these partisan skirmishes, writers struggled to distinguish the significant from the merely distracting, sometimes changing company as they did so:

Swift, Davenant, Defoe-to go no further-were found in differing company at different times of their lives; and . . . these changes of front are best explained not by attempting to assess questions of commitment and consistency, venality and ambition, but by recognizing that they were employing a highly ambivalent rhetoric, replete with alternatives, conflicts, and confusions, of which they were very well aware and in which they were to some extent entrapped. ${ }^{18}$

There were undoubtedly voices crying that the Church was in danger or deploring the approach of absolutism and popery, but the most

16. Cf. Herman, Business of a Woman, 86.

17. Toni Bowers, Force or Fraud: British Seduction Stories and the Problem of Resistance, 1660-1770 (Oxford: Oxford University Press, 2011), 189-90.

18. J. G. A. Pocock, The Machiavellian Moment: Florentine Political Thought and the Atlantic Republican Tradition (Princeton: Princeton University Press, 1975), 446. That there was a coherent, neo-Harringtonian opposition has been challenged, but in his quest for satire, D. N. DeLuna may over-fragment it: see his "Topical Satire Read Back Into Pocock's Neo-Harringtonian Moment," in The Political Imagination in History: Essays Concerning J. G. A. Pocock, ed. D. N. DeLuna, assisted by Perry Anderson and Glenn Burgess (Baltimore: Owlworks-Archangul Foundation, 2006), $129-73$. 
profound cultural divisions were felt within social groupings and extended across them. To the reader of contemporary political satire, that celebrated trope for an Augustan order, concordia discors, looks like a profound yearning fuelled by fear that all-too-obvious social fragmentation would again lead to civil war.

Not one to mince words, Carole Fabricant has called contemporary Toryism "schizophrenic," an ideology "characterized by contradictory impulses and serving as a political umbrella for highly disparate groups in society," including urban and rural, high and low. ${ }^{19}$ Only a writer as partisan (and politically naive) as Swift could have failed to suspect as much once he jumped to a ship where the office of the captain, held by the former Whig Robert Harley, was coveted by Harley's charismatic and treacherous first mate, Henry St. John. I resist only Fabricant's implication, perhaps unintentional, that their "common opposition to the wealthy commercial and urban monied interests" identifies a less self-divided foe. Striking internal contradictions characterized the Whigs, too, most visibly but by no means only in the split between Court and opposition Whigs. ${ }^{20}$ We cannot read ideologically complex texts if we accept the caricature that all Tories championed passive obedience to the king, all Whigs a resumption of an original contract. Even the Revolution of 1688-89, often treated popularly as a Whig event, had a Tory cast: "If we ask who was responsible for defeating the drift towards popery and arbitrary government under James II," Tim Harris argues, "the answer has to be the Tory-Anglican establishment," composed not of "royal absolutists" but of "conservative legal-constitutionalists, deeply committed to the rule of law and the Anglican Church." Under Anne, Whigs could still sometimes make hay of Tory responsibility for the Revolution. ${ }^{21}$ Whigs shaped it in ways Tories resented, but with their leaders dead or in exile by the time James II and VII came to the throne, they could not have brought the Revolution about.

19. Fabricant, "Shared Worlds," 169.

20. J. G. A. Pocock, "The Varieties of Whiggism from Exclusion to Reform: A History of Ideology and Discourse," in Virtue, Commerce, and History: Essays on Political Thought and History, Chiefly in the Eighteenth Century (Cambridge: Cambridge University Press, 1985), 215-310; Mark Goldie, "The Roots of True Whiggism 1688-94," History of Political Thought 1, no. 2 (Summer 1980): 195-236.

21. Politics Under the Later Stuarts: Party Conflict in a Divided Society $1660-1715$ (London and New York: Longman, 1993), 119, 141. 
Recognizing that Swift and Manley were partisans who practiced a recognized, ideologically freighted literary form does not deny their political or literary differences. A High-Church supporter of the Revolution, Swift could have found a slightly uncomfortable home with either the Whigs or the Tories. But he published the Tale volume as a Whig, dedicating it to the head of the Whig Junto. Manley, on the other hand, was a Tory who published New Atalantis in 1709 to discredit those very Whigs. But their common form does allow us to differentiate them precisely on grounds other than gender or assumed literary merit. By the practical criterion of effectiveness, Manley wrote by far the more successful political satire. The New Atalantis had what it was intended to have, an impact on practical politics. It contributed to the fall of the Whig administration that was voted out in the election of $1710 .{ }^{22}$ Although A Tale of a Tub caught the public eye as a work of outrageous genius, it neither gained Swift preferment nor affected political events. His learned and vigorously argued political debut had also failed. A defence of the lords of the Whig Junto (who figure among Manley's targets) when they faced impeachment by the House of Commons, A Discourse of the Contests and Dissentions between the Nobles and Commons in Athens and Rome (1701) appeared in print only after the lords had been acquitted. ${ }^{23}$ Swift's deserved reputation as a remarkably effective propagandist rests on his work under close political supervision, first by Robert Harley's ministry in England and later under Archbishop King and others in the Anglo-Irish establishment, for whom he wrote the Drapier's Letters. His cherished independence was perhaps unsuited to something as collaborative and contaminating as politics. A characteristic Swiftian "note of bitter vexation," David Womersley argues, reflects "Swift's resentment of the intimate deformation of his character as a writer caused by the political hack-work

22. Paula McDowell, The Women of Grub Street: Press, Politics, and Gender in the London Literary Marketplace 1678-1730 (Oxford: Clarendon Press, 1998), 243-44; Bowers, Force or Fraud, 163.

23. On the distinctiveness of Swift's early Whig position, see Mark Goldie, "Situating Swift's Politics in 1701," in Politics and Literature in the Age of Swift: English and Irish Perspectives, ed. Claude Rawson (Cambridge: Cambridge University Press, 2010), 31-51; on the extent to which he could fit into either party, see David Oakleaf, A Political Biography of Jonathan Swift (London: Pickering and Chatto, 2008), 79-81. 
upon which he was engaged" under Harley. ${ }^{24}$ By the time Swift proved himself as editor of the Examiner, a task at which she followed him, Manley had established herself as an exuberant and masterful political propagandist. ${ }^{25}$ Prince Posterity is not the only judge of political satire.

That A Tale of a Tub and The New Atalantis both attracted readers on terrain fiercely contested by rival parties also invites us to associate Swift and Manley as professional writers appealing to the marketplace. In the years between Pilgrim's Progress (1678), with twelve editions in its author's lifetime, and Robinson Crusoe with nine (four of them in the first four months), Swift and Manley appealed to the appetite for partisan fiction as well as anyone. ${ }^{26}$ A Tale of a Tub went through three editions in 1704, a fourth in 1705; Swift revised it covertly but significantly for the fifth edition of 1710 , after which it continued to be reissued (A Tale, 275-83). He maintained his control over his text-indeed, his revision increased it by satirically absorbing his critics in his textual apparatus - at the price of publicly distancing himself from it: the clergyman could not openly acknowledge his authorship of a work widely attacked as godless. The textual history of The New Atalantis is more obscure, but there is no doubting its immediate success. It exaggerates that success to claim, with one critic, that "there were at least 7 editions produced over the first half of the eighteenth century" and that "reprints of these editions appeared throughout the remainder of the century." ${ }^{27}$ If we except Queen Zarah (and its important, plagiarized Preface) as probably not Manley's despite the common attribution to her, my searches in the online catalogues of the British Library, the Bodleian, and the OLCL World Catalogue turn up no eighteenthcentury editions of the Atalantis (or collections of Manley) after 1741, when anticipation of Walpole's fall briefly renewed its currency as

24. Jonathan Swift, Gulliver's Travels, ed. David Womersley (Cambridge: Cambridge University Press, 2012), lix.

25. On Swift's developing skill as a political writer, see James McLaverty, "Swift and the Art of Political Publication: Hints and Title Pages, 1711-1714," in Politics and Literature in the Age of Swift: English and Irish Perspectives, ed. Claude Rawson (Cambridge: Cambridge University Press, 2010), 116-39.

26. John Bunyan, The Pilgrim's Progress: An Authoritative Text, Contexts, Criticism [1678, 1684], ed. Cynthia Wall (New York: Norton, 20o9), xvii; Daniel Defoe, Robinson Crusoe, 1719, ed. Thomas Keymer, with notes by Thomas Keymer and James Kelly (Oxford: Oxford University Press, 2007), xl

27. Santesso, "New Atalantis," $200 n 1$. 
opposition propaganda. ${ }^{28}$ In the edition of works by Manley that she co-edits with Ruth Herman, Carnell casts a properly wary eye on title page edition statements. She identifies at least six editions of the Atalantis - two in 1709, others in 1716, 1720, 1736 and 1741, both the latter two called the "seventh." (Manley, 2: 1)

There are, Atalantis demonstrates, textual as well as political hazards of committing oneself to print. Manley exploited the scandalous reputation for authorship that got her arrested, but she forfeited the control over her text that Swift rigorously maintained. The booksellers apparently rushed to cash in on the publicity surrounding her arrest. All the signs point toward a large print run as well as hasty publication of the second edition that capitalized on Manley's arrest:

Numerous variants of a "second edition" of the two volumes also appeared in 1709. Although all of these variants were, like the first edition, "printed for John Morphew and J. Woodward," some printers seem to have taken it upon themselves to make a variety of minor corrections in punctuation and capitalization; others did not. There is, thus, no definitive "corrected" edition. Subsequent "editions" are, again, not properly corrected editions, in the modern sense; for example, the "sixth edition" has fewer corrections than one variant of the "second edition." (Manley, 2: 1)

A fellow participant in Grub Street, a fellow satirist, and a fellow writer of undoubted political importance, Manley cultivated her scandalous public identity in ways that Swift, as a clergyman, could not. ${ }^{29}$

Both writers prospered in the discursive street fight that passed for partisan debate, offering readers guides through a morass in which satire and fiction shared common ground with political argument. Swift's The Conduct of the Allies (1711), which can perhaps represent purely partisan argument, also tells a compelling story of England's good intentions and its allies' perfidy. Swift contributed it to a discourse that already included Manley's The New Atalantis and its sequel, Memoirs of Europe (1710), partisan satiric fictions that helped bring the

28. John L. Sutton, "The Source of Mrs. Manley's Preface to Queen Zarah," Modern Philology 82 (November 1984): 167-72; J. A. Downie, "What If Delarivier Manley Did Not Write The History of Queen Zarah?” The Library 5, no. 3 (2004): 24764; Herman, Business, 236.

29. McDowell, Women of Grub Street, 215-84; cf. Herman, Business and Rachel Carnell, A Political Biography of Delarivier Manley (London: Pickering and Chatto, 2008). 
Tories to power. His friend John Arbuthnot's History of John Bull, a series of five pamphlets published in 1712 , served the same partisan cause of peace through its homely, entertaining stories of John Bull's entanglement in a ruinous lawsuit. Arbuthnot's modern editors argue that Arbuthnot writes in a recognizable if "very minor genre," "the allegorical 'little history' form so popular with Tory satirists in the reign of Anne"-surely the form to which A Tale's story of three brothers and their coats also belongs. (Any given Varronian satire has room for stories, for stories within stories.) They nod to Manley as "the most celebrated contemporary theorist and practitioner of this genre," perhaps the reason that the title pages of the third and subsequent pamphlets claim to be "Publish'd . . . by the Author of the New Atalantis": associating the John Bull pamphlets with a successful earlier Tory propagandist obviously did the Tory brand no harm. ${ }^{30}$ Manley held an acknowledged place in Swift's milieu.

Once the 1716 Septennial Act "took much of the sting out of electoral politics" by making elections less frequent, former propagandists like Swift, Manley, and Daniel Defoe-and new professional writers like Eliza Haywood-had to appeal to readers in new ways. ${ }^{31}$ Ros Ballaster remarks dryly that there were "pragmatic political and ideological reasons for a return to romance proper in the 1720s"; "both Swift and Defoe, noted for their political journalism in the last four years of Anne's reign," she adds, "turned to fiction as their major medium in the 1720 s." ${ }^{2}$ It is surely no coincidence, that is, that the lively resurgence in the market for fiction inaugurated by the Love in Excess and Robinson Crusoe in 1719 (and promptly followed by Manley) follows about three years after the Septennial Act knocked the bottom out of the bull market for partisan propaganda. ${ }^{33}$ If "Manley's The Power of Love [1720] and Haywood's Love in Excess [1719-20] mark a shift in the

30. John Arbuthnot, The History of John Bull, ed. Alan W. Bower and Robert A. Erickson (Oxford: Clarendon, 1976), lxxvii-lxxviii.

31. Julian Hoppit, A Land of Liberty? England 1689-1727 (Oxford: Clarendon Press, 2000), 48-49, 28-29.

32. Ros Ballaster, Seductive Forms: Women's Amatory Fiction from 1684 to 1740 (Oxford: Clarendon, 1992), 155-56.

33. On this fiction boom, see Cheryl Turner, Living by the Pen: Women Writers in the Eighteenth Century (London: Routledge, 1992), 37 Fig. 5, 38-39; J. A. Downie, "Mary Davys's 'Probable Feign'd Stories' and Critical Shibboleths About 'The Rise of the Novel'," Eighteenth-Century Fiction 12, no. 2-3 (January-April 2000): 309-26. 
nature of amatory fiction by women," as Ballaster claims, Manley was following her younger and, in this instance, more successful contemporary into the new market. Her title suggests an attempt to cash in on the success of Haywood's first novel, which had six editions in the author's lifetime. ${ }^{34}$ Manley was a professional alert to market trends.

What Ballaster calls "a return to romance proper" from scandal romance-she has her eye on the early Haywood's apparent lack of partisan affiliation-I see as a remarkably inventive engagement with a commercial marketplace that was no longer driven by the "political instrumentality" 35 that had given partisan pamphlets like Manley's their raison d'etre, and had won patrons or pay for the ablest pamphleteers. Kathryn R. King has shown that between 1713 and 1725 , the Jacobite novelist Jane Barker-almost definitively a writer denied Manley's and Swift's instrumentality in the service of accepted political parties - engaged in a series of increasingly commercial fictions in which she worked through her "complex elegiac responses to the declining fortunes of the exiled Stuarts and their followers in England." ${ }^{36}$ Narratives of seduction, Toni Bowers shows, allowed Tories in particular to think through questions of obligation, choice, and (crucial to their view of monarchy) resistance and collusion. Such studies illuminate the links between late seventeenth-century courtesan narratives and the fiction of Richardson and Fielding, which was, Alison Conway shows, shaped by those conflicts. Thus the hero's sordid intrigue with Lady Bellaston in Henry Fielding's Tom Jones echoes Manley's Lady's Pacquet of Letters (1707), and Defoe's Roxana suggests how long and how consistently English fiction, whiggish as well as tory, wrestled with the implications of dynastic upheaval through which the English (later the British) resolved the struggle for authority between monarch and parliament. ${ }^{37}$

34. Ballaster, Seductive Forms 153; Patrick Spedding, A Bibliography of Eliza Haywood (London: Pickering and Chatto, 2004), 88.

35. Ballaster, Seductive Forms, 157.

36. Kathryn R. King, Jane Barker, Exile: A Literary Career 1675-1725 (Oxford: Clarendon, 2000), 147 .

37. Alison Conway, The Protestant Whore: Courtesan Narrative and Religious Controversy in England, 1680-1750 (Toronto, Buffalo and London: University of Toronto Press, 2010), 171-74, 110-41; on the political thrust of the Jacobite Rebellion as it appears in Tom Jones, see J. A. Downie, A Political Biography of Henry Fielding (London: Pickering and Chatto, 2009), 173-84. 
Writers who turned to fiction in the 1720 s competed in a marketplace no less contested than the one A Tale of a Tub and the New Atalantis had entered. In crafting less instrumental fictions to appeal to those they perhaps thought of as "their" readers, writers dealt in a rhetoric no less highly ambivalent, no less "replete [in Pocock's Fieldingesque phrase] with alternatives, conflicts, and confusions" than they had as propagandists. That they did not always sell as well as they had hoped is no proof that they were not trying. A not very successful exercise in an old form, the collection of tales, Manley's The Power of Love: In Seven Novels is "stylistically and thematically old-fashioned," its editor claims, most of its contents translated and adapted from hoary material long available (Manley 1: 40). Yet it is no sign of declining power. Manley had long been adapting existing materials to current needs. She had "pulled together . . . scraps" in Atalantis, too, including the "strikingly borrowed" apple pie episode: the strategy helped to deflect legal prosecution of the satirist. ${ }^{38}$ McDowell encourages us to see Manley's writing as a place of intersection and interaction:

To see Manley's polemical fictions as a site where traditions conjointhe highly gender-conscious but still largely aristocratic tradition of seventeenth-century fiction and the broader tradition of middling and lower-class women's political activity through print-is to begin to understand just how doubly important-and threatening-she was. ${ }^{39}$

Manley offers glimpses of links between political and personal, between Swift's patrician manner and Defoe's challenge to its assumptions. Intelligence tells her tale to travelling goddesses, surely the most aristocratic of audiences.

Usefully reminding us that Defoe was a considerable satirist, Marshall describes the method of his indirect satires as "articulating a position in such a way as to expose it," and there can be no doubt that his Shortest-Way with the Dissenters challenges assumptions Swift found congenial. "I read The Shortest-Way," she adds, "not as insufficiently ironic but as counterfeit, an intentional fake" exposing the underlying logic of the High-Church position. ${ }^{40}$ This is persuasive and illuminating. Defoe's contemporaries seem to have registered as an

38. Sargent, "How a Pie Fight," 529-30.

39. McDowell, Women of Grub Street, 223.

40. Marshall, Practice of Satire, 156-57. 
innovation his narrative focus on the varied adventures of a singular individual. Jane Barker pitted her patchwork against the popularity of "Histories at Large," specifying three novels we attribute to Defoenot then known to be his-as well as the scandalous biography of Sally Salisbury I quoted above. ${ }^{41}$ Identifying the same trend, Mary Davys complained in 1725 that "History and Travels" have driven "those Sort of Writings call'd Novels . . out of Use and Fashion." ${ }^{\text {+2 }}$ Defoe in fact never published a novel under his name, preferring to present pseudoautobiographies allegedly written by the protagonist or, as the title page of Moll Flanders proclaims, from "her own Memorandums." Like Shortest-Way as Marshall reads it, they are counterfeits. Novelists like satirists, moreover, often hinted that they represented thinly disguised events in high life. In a now recognized example of professional rivalry, Defoe's venture into secret history, The Fortunate Mistress (1724), which we call Roxana, responded to Haywood's Idalia; or, The Unfortunate Mistress (1723). ${ }^{43}$ Less to their professional dignity, both Haywood and Defoe were opportunistically exploiting the publicity surrounding a real event, the trial for attempted murder and subsequent death in prison of Sally Salisbury, the courtesan I mentioned above..$^{44}$ Reading the hazards and allure of singularity as a recurrent theme of eighteenth-century fiction, April London observes of the ending of Roxana that it "reanimates the terms of secrecy and doubling and reinstates volatility as a guiding principle"-distinguishing (and residually political) features of the selves at the centre of Defoe's fiction. ${ }^{45}$ That Swift's

41. Jane Barker, The Galesia Trilogy and Selected Manuscript Poems of Jane Barker, ed. Carol Shiner Wilson (New York: Oxford University Press, 1997), 31. Defoe's novels other than Robinson Crusoe were attributed to him only late in the eighteenth century; see P. N. Furbank and W. R. Owens, "Defoe and Francis Noble," Eighteenth-Century Fiction 4, no. 4 (July 1992): 301-13.

42. Mary Davys, The Reform'd Coquet; or Memoirs of Amoranda, Familiar Letters Betwixt a Gentleman and a Lady and The Accomplish'd Rake, or Modern Fine Gentleman, ed. and introd. Martha F. Bowden (Lexington: University Press of Kentucky, 1999), 87; J. A. Downie, "Mary Davys's 'Probable Feign'd Stories' and Critical Shibboleths About 'The Rise of the Novel'," Eighteenth-Century Fiction 12, no. 2-3 (January-April 2000): 309-26.

43. Hammond and Regan, Making the Novel, 52-53.

44. See David Oakleaf, "Testing the Market: Robinson Crusoe and After," in The Oxford Handbook of the Eighteenth-Century Novel, ed. J. A. Downie (Oxford: Oxford University Press, forthcoming).

45. April London, The Cambridge Introduction to the Eighteenth-Century Novel (Cambridge: Cambridge University Press, 2012), 32-33; for the argument that Roxana 
Travels into Several Remote Nations of the World parodies, in particular, Defoe's truth claims by invented narrators, is consistent with the parody of self-revealing selves he began in A Tale of a Tub.

For unlike Defoe, Swift signposts his ironies when he parodies the alarming instability of a fashion-obsessed commercial world through the self-pitying, self-sabotaging and relentlessly digressive voice of his Tale-Teller:

even, I my self, the Author of these momentous Truths, am a Person, whose Imaginations are hard-mouth'd, and exceedingly disposed to run away with his Reason . . .; upon which Account, my Friends will never trust me alone, without a solemn Promise, to vent my Speculations in this, or the like manner, for the universal Benefit of Human kind. . . . (A Tale, 116)

Only in peculiar circumstances could a confession that one is selfimportant and suicidal confer narrative authority: Swift captures a distinctively modern voice even as he satirizes the modernity that fascinated him and his contemporaries. ${ }^{46}$

Manley instead represents the mutability of the modern commercial modern world as a radical inconstancy, the sexual correlative of power that is arbitrary because unmoored from land ownership. In what is now the Atalantis's most celebrated episode, a duke who obviously but not explicitly represents the first earl of Portland corrupts and rapes his ward Charlot. Yet Manley shows none of Haywood's interest in the victim's inner life. She does, momentously, make the private abuse of a young woman the test of fitness to wield public power, but Charlot is the narrative equivalent of a kid staked out to attract a tiger. The satirist's intended prey is the predator drawn to this bait. When the writer moralizes, we learn that young ladies should not take to heart the vows that sexually urgent men whisper in their ears. To this banal lesson, Astrea herself adds, “"That no Woman should introduce another to the Man by whom she is belov'd; if that had not happen'd, the Duke had not possibly been false" (Manley 2: 54). Only in a deeply corrupt world-and this is likely Manley's point-could such cynical

looks not merely unstable but mentally ill, see Raymond Stephanson, "Defoe's 'Malade Imaginaire': The Historical Foundation of Mental Illness in Roxana," Huntington Library Quarterly 45, no. 2 (Spring 1982): 99-118.

46. On the unstable modern personality's place in political discourse, see Pocock, Machiavellian Moment, 458-59. 
advice masquerade as wisdom. The satirists Swift and Manley had no more interest than later novelists in credulous readers who would nod uncritically when a narrator makes a pronouncement.

It is hard to say where the Varronian shades into the various, but a prying gaze and the miscellaneousness of Varronian satire may be the most enduring legacies of the political satire Swift and Manley practiced with such mixed success. The collection of miscellaneous narratives took a modern form when it reconfigured itself as a correspondence broken into. Charles Gildon exploited this phenomenon early in The Post-Boy Rob'd of His Mail; or, The Pacquet Broke Open (1692-3) and late (in the heyday of Defoe and Haywood) in The PostMan Robb'd of His Mail; or, The Packet Broke Open (1719). To this tradition Manley contributed Letters Written by Mrs. Manley (1696) and The Lady's Pacquet of Letters (1707). ${ }^{47}$ The promise is to expose secrets of the private selves into which the modern world seemed to some to have fragmented. In A Patch-Work Screen for the Ladies (1723), King shows, Jane Barker recuperated and feminized this kind of miscellany. Surveying Barker's career, King conjectures that "the popularity of Jacobite romance in its own moment suggests, we might say, the existence of reading public that understood itself less in terms of unity and coherence than of national heterogeneity-a patchwork public, if you will." ${ }^{\prime 8}$ Heterogeneity may at times be meaning. King has since observed that Haywood, a novelist who began her career after the rage of party, was "a mistress of multiplicity almost from the start," one in whom secrets and curiosity are recurrent themes. ${ }^{49}$ The deep implication of politics and satire in later, less instrumental fictions suggests that others may have shared that sense of incoherence and that curiosity. We should read into our histories of eighteenth-century fiction the satirists and polemicists who had addressed as partisan writers the political contradictions and confusions from which others, like them, later crafted imaginative fiction.

47. Thomas Keymer deftly surveys this terrain in "Epistolary Writing in the Long Eighteenth Century," in A Companion to British Literature, Volume III: Long Eighteenth-Century Literature, ed. Robert DeMaria, Jr., Heesok Chang, and Samantha Zacher (Chichester: Wiley-Blackwell, 2014), 159-73; on Manley's epistolary fiction, see Manley 1: 9-14.

48. King, Jane Barker, 193-98, 179.

49. Kathryn R. King, A Political Biography of Eliza Haywood (London: Pickering and Chatto, 2012), 193-201. 